\title{
THE DISPOSAL OF THE SEWAGE OF SEASIDE TOWNS.
}

\author{
By J. T. O. NASH, M.D., D.P.H.,
}

Medical Officer of Health, Southend-on-Sea.

(MEMBER.)

THE question of sewage disposal is a very large one bristling with 1 difficulties, and though an important Royal Commission has been sitting on the subject for several years, no final recommendations as to methods of treatment are yet forthcoming from the Commissioners in spite of their vast labours.

There are in my opinion no very serious objections to the present methods of disposal by discharge into the sea which are not also applicable to treated sewage, but there are some minor ones chiefly of an asthetic or sentimental nature.

The only serious objection that can be made, where the outfall is carried well out to sea, applies to sewage effluents as well as to ciude sewage (though perhaps in a lessened degree), and that is bacterial injury to fish. Were sea-coast towns to spend huge sums of money on some of the most approved modern methods of treatment, the effluent would still be "potentially dangerous," as stated by the Royal Commission on Sewage Disposal in their "Fourth Report on the Pollution of Tidal Rivers, with special reference to contamination of shell-fish." The following significant sentence occurs in this Fourth Report of the Commissioners:"The treatment of sewage, according to methods at present in use, canmot be relied on so to alter its character as to allow of its discharge in the immediate neighbourhood of shell-fish layings without incurring appreciable risk of disease being communicated by the consumption of shell-fish taken from such layings."

Whether it be the sewage of an inland town or that of a seaside resort, the questions involved as to the disposal of sewage are very intricate, and "due regard must be had in each case to the extent of the eril, to the possibility of providing a remedy, and to the cost." 
The first question then is as to the extent of the evil. In the case of an inland town this is generally a very serious question indeed. The evil is great, and must somehow or another be, to some extent at least, remedied by some method of sewage treatment.

In the case of a sea-coast town, the provisions of nature are such that no serious evil need exist, provided that the outfall is carried sufficiently far from the shore at a position indicated by careful examination of currents and tides by means of float experiments or by other accurate observations.

If the grosser suspended solids are kept back by the simple means of screenings, these can be burnt or dug into the ground forthwith. The dissolved solids then pass out into the sea; some of these are at once precipitated by the salts contained in the sea-water; the remainder meet with enormous quantities of dissolved oxygen contained in the constantly changing huge volumes of sea-water, and are rapidly oxidised and purified.

If crude sewage or a sewage effluent is discharged into a narrow creek on a falling tide so that it does not meet with changing quantities of fresh sea-water charged or saturated with oxygen, but on the contrary forms a larger and larger proportion of the water in the creek as the tide ebbs, it is obvious that such a sewage or effluent does not and camnot immediately meet with sufficient quantities of dissolved oxygen to oxidise its organic matters forthwith, and will not do so until the next tide begins to flow.

If, on the other hand, it enters the sea or a broad estuary several miles in wilth, even though it be the untreated sewage of a very large town, its comparative quantity is very small as compared with the mighty changing volumes of water into which it is gradually discharged. The value of the fact that it is discharged into a vast restless moving body of water is also not to be ignored. In consequence of this each volume of sewage enters a fresh and much larger volume of clean water, which experiments have shown to be freely supplied with dissolved oxygen.

The truth of the natter is that the sea provides an inexhaustible supply of dissolved oxygen. We have already seen that the object of bacteria contact beds is to secure oxidation of sewage. In the sea we have, in my judgment, moving liquid contact beds providing all the oxygen necessury for oxidution.

Where then the diluting fluid is thousands of times greater in volume than the sewage (crude or effluent) entering it, the clissolved oxygen in the diluting water is amply sufficient to effect oxidation, but in this process many creatures, macroscopic and microscopic, assist, and it is really 
astonishing how rapidly all traces of sewage matter disappear. Where unscreened sewage is entering the sea a few small fœcal masses may float like corks on the water for varying distances, but even these eventually dissolve and disappear. Still as this takes time it is obviously advantageous to remove such solid particles by means of screening before discharging the sewage.

In certain sea-coast towns a nuisance indirectly arising from the discharge of sewage is occasionally met with. This arises from the growth of large quantities of sea-weed, particularly a sea-weed known by the name of Ulva latissima. Professor Letts, of Belfast, has carried out some very valuable experiments in connection with this sea-weed, and has shown that it is a natural purifier of a sewage-polluted sea-water, itself giving out oxygen and absorbing large quantities of nitrogen. For this latter reason, if the sea-weed collects in large quantities and is thrown up on to a foreshore, and is there exposed to the rays of the sun, it putrefies rapidly, giving rise to an almost intolerable stench.

Professor Leits in two valuable reports has shown that this sea-weed cau absorb nitrogen either from free ammonia, which is abundant in both treated and untreated sewage, or from nitrates which are found, and indeed are required to be found, in a grood sewage effluent after treatment.

Chemical examinations carried out by myself and others show that there is very little free ammonia in the water of the Thames about the position where this sea-weed is tending to accumulate, but one would expect the water of a river like the Thames to be bringing down considerable quantities of nitrates, which indeed are quite appreciable in the estuarial waters.

It will be understood from what I have already said, that provided the growth of this sea-weed can be kept within bounds and the weed prevented from being cast up on the foreshore in large quantities, it is really a useful scavenging or purifying agent in any polluted water.

Were jt, however, to grow too profusely and not be kept under control, and were it to be cast up on the foreshore within reach of the tides, it might in the hot months give rise to an undoubted nuisance in the way of an almost intolerable stench.

Professor Letts suggests that it might be possible to utilise the seaweed Ulva latissima as an agent for the final purification of sewage by means of an "Aquatic Sewage Farm." This suggestion appears to me to be scientifically (and I hope practically) an excellent one. There can be little doubt that these green sea-weeds are among the purifying agencies which nature has designed for dealing with sewage in sea-water. 
Acting on this idea he has recommended that tanks or ponds could be constructed on the flat Slob lands of Belfast so as to contain sea-water and living Ulia latissima. The tanks could be made tidal in their action, and any excess of growth of the Ulea could be dealt with by removal. Such Ulva indeed would form an excellent manure, as the value of a manure depends chiefly upon the amount of nitrogen, phosphoric acid, and potash salts which it contains, and more especially the proportions of the two former.

Letts has shown that the Ulva may be considered to be almost equivalent to a sample of farmyard manure in respect of phosphorus, while greatly superior to it as regards nitrogen. Farmers would thus find the cost of carting a remunerative investment.

I have not heard whether his suggestion has ever been acted upon, and his final report has not yet been published; but he kindly informs me that a long and detailed report by Dr. Adeney and himself on the pollution of estuaries and tidal waters (for the Royal Commission on Sewage Disposal) is now in the Press.

In certain cases it might be possible to consider a site for a refuse destructor in connection with a proposed sewage scheme, for the heat generated by the destruction of the refuse might be utilised for pumping purposes, and the clinker might come in useful in various ways, as for instance for making a contact bed, should it be decided to further treat the sewage before discharging. On a flat shore such a bed might be constructed on the flats, and be made tidal in action; the idea would then be rather to use such a bed more as a mechanical than as a biological filter, though I think it would not altogether lose its biological qualities even if flushed with sea-water daily. The effluent from such a bed could then pass through an Olva lagoon, as suggested by Letts, and so to the sea.

Letts very kindly writes me: "While these (green) sea-weeds are admirable purifiers in relation to soluble impurities such as ammonia, they of course do not affect the solids in suspension, nor do they diminish the amount of albuminoid matters. Therefore they could only be used as a method of treatment in very special cases."

It is worth noting that a ton of sulphate of ammonia, a valuable commercial product worth about $£ 11$ per ton, can be obtained from 14 tons of the dry sea-weed, whereas it requires 25 tons of coal to give the same quantity. It seems possible therefore that an aquatic sewage farm might prove to be a profitable undertaking.

The method of disposal of sewage that would seem to be sufficient for a sea-coast town would thus be (1) screening off of grosser solids; (2) 
precipitation and liquefaction in tanks of sufficient size to hold a day's dry weather flow. This would permit of partial anaerobic bacterial treatment and consequent breaking down of the contained organic matter; (3) the effluent to be discharged at an outfall sufficiently far from the shore. In no case should the outfall terminate on the foreshore. It should always be covered with water, even at low water of spring-tides.

If further treatment on the lines indicated could be carried out, it would appear that a satisfactory effluent might be discharged, and possibly at small expense, or even at a profit in time. The method appear's to be worthy of experimental trial in suitable cases.

I do not think that sea-board towns should be saddled with the cost of expensive methods of treatment such as are unfortunately necessary in the case of inland towns. The sea in itself constitutes better oxidising contact beds than any expensive artificial contact beds, but sentiment if nothing else calls for some preliminary reduction of impurity prior to discharging sewage even into the sea, and the forthcoming reports of Drs. Letts and Adeney should prove of great interest.

Among the unsolved problems in the disposal of the sewage of large towns, are the questions of overflow and of storm water in times of rain.

If ever the time comes when the horse and the dog are tabooed in cities, the storm water problem will have shrunk into comparative insignificance; but as long as horse traffic predominates, the first washings of streets in times of storm, after a period of dry weather, must be indescribably filthy.

In my judgment the first washings of streets should always reach the main sewers. 